\title{
Comparative phylogeography of two sister (congeneric) species of cardiid bivalve: Strong influence of habitat, life history and post-glacial history
}

\author{
Katarzyna Tarnowska a,b, Manuela Krakau ${ }^{c}$, Sabine Jacobsen ${ }^{c}$, Maciej Wołowicz $^{\mathrm{b}}$, Jean-Pierre Féral ${ }^{\mathrm{a}}$, \\ Anne Chenuil ${ }^{\mathrm{a}, *}$ \\ ${ }^{a}$ IMBE (Mediterranean Institute of Biodiversity and marine and continental Ecology) - UMR 7263, CNRS, Université Aix-Marseille, France \\ ${ }^{\mathrm{b}}$ Laboratory of Estuarine Ecology, Institute of Oceanography, University of Gdańsk, Al. Pitsudskiego 46, 81-378 Gdynia, Poland \\ ${ }^{\mathrm{c}}$ Wadden Sea Station Sylt, Association Alfred Wegener Institute for Polar and Marine Research, Hafenstr. 43, D-25992 List, Germany
}

Keywords:

Cerastoderma

genetic diversity

habitat

phylogeography

sister species

\begin{abstract}
A B S T R A C T
Sister (congeneric) species may exhibit disparate patterns of biogeographic genetic structures due to different life histories and habitat preferences. The common cockle Cerastoderma edule and the lagoon cockle Cerastoderma glaucum probably diverged from their common ancestor in the present territory of Sahara around 5 million years ago. Although it is difficult to separate both species morphologically, various genetic markers, both mitochondrial and nuclear, clearly distinguish them. Furthermore, their lifestyles are different, as $C$. edule has a much less fragmented coastal habitat and a longer duration of pelagic larval stage than $C$. glaucum. A comparative genetic analysis was conducted on 17 populations of C. edule and 13 populations of $C$. glaucum using a 506 bp fragment of mitochondrial DNA (COI). We tested the hypothesis that differences in habitat types and life history are reflected in the genetic structure patterns of these two cockles. Indeed substantial differences in population genetic structures between them are revealed. Genetic diversity within $C$. glaucum populations decreases northwards as a consequence of post-glacial (re)colonization from southern refugia, while C. edule displays an opposite pattern indicating survival in glacial refuges in the northern Atlantic. Among populations within geographic groups, genetic differentiation is low in C. edule, probably as a result of larval dispersal with coastal currents, while it is extremely high in C. glaucum, best explained by the fragmented habitats. Interestingly, long distance divergence is less expressed in $C$. glaucum than in $C$. edule, which supports the speculation that migrating birds (frequently observed in lagoons) may occasionally transport the former more often or more efficiently than the latter. The approach applied in this study (e.g., rarefaction procedure, selection of samples of both species from the same regions) enabled a new and reliable comparative analysis of the existing raw datasets.
\end{abstract}

\section{Introduction}

Closely related (congeneric) species may exhibit contrasting patterns of population genetic structure due to various factors (i.e., biological, ecological, physiological, behavioral, physical, geological or environmental) (Bermingham and Moritz, 1998). In sessile coastal invertebrates, life history traits (e.g., direct development versus planktonic larvae) mainly determine dispersal capacity (Teske et al., 2007). Various geographic and hydrological barriers, as well as habitat preferences influence dispersal success and consequently the level of gene flow (Palumbi, 1994; McMillen-Jackson and Bert, 2003). Present genetic patterns are also shaped by the environmental history of the region, mainly Pleistocene glaciations, which rendered most areas of northern Europe uninhabitable (Maggs et al., 2008). Therefore, comparative assessments of the population genetic structures of closely-related species give the opportunity to understand factors influencing evolutionary processes on different time scales.

The cardiid bivalves Cerastoderma glaucum and Cerastoderma edule diverged from their common ancestor in the Mediterranean Sea and the present territory of Sahara during late Miocene (Rygg, 1970; Levy, 1985; Brock and Christiansen, 1989; Hummel et al., 1994; Nikula and Väinölä, 2003). This divergence was probably the result of the Messinian salinity crisis during which the Mediterranean was split into a number of isolated basins and lagoons with different salinity conditions (Hsü et al., 1977). These 
paleogeographic and paleoclimatic events have played an important role in the evolutionary history of several marine taxa (Hanel et al., 2002; Costagliola et al., 2004 and references therein; Valsecchi et al., 2005) including cardiids (Müller et al., 1999). According to the allopatric speciation scenario, which is the most likely for the two cockles, $C$. glaucum evolved in the area of the present Mediterranean Sea in basins with changing salinity and became adapted to a great salinity range. During isolation by low sea level, $C$. edule colonized the coast of the Atlantic Ocean characterized by its tidal movement and alongshore currents. In later times, $C$. glaucum managed to spread northwards in competition with $C$. edule and settle down at some patches along the Atlantic coast, probably because of its tolerance of non-tidal water (see below) (Ansell et al., 1981). In contrast, C. edule did not recolonize the inner Mediterranean (Rygg, 1970). Taking into account the morphological similarity of the two cockle species, it is hard to find definite fossil proof of their divergence scenario. Both taxa have even similar spawning periods and may co-inhabit calm sea grass areas or bights along the Atlantic coast. However, crossfertilization was never recorded, neither in experimental nor in natural conditions (Kingston, 1973; Brock, 1978; Gosling, 1980). There are a few criteria for morphological distinction between the two species, but none of them seemed to enable unequivocal separation at all sites of co-occurrence (Brock, 1978; Machado and Costa, 1994). Nevertheless, biochemical criteria and genetic markers are able to clearly distinguish both cockles (Brock, 1978; Brock, 1987; Brock and Christiansen, 1989; Hummel et al., 1994; André et al., 1999; Nikula and Väinölä, 2003; Freire et al., 2005; Ladhar-Chaabouni et al., 2010). Microsatellite primers designed for C. glaucum did not amplify DNA from C. edule, which also proves the separate character of these species (personal observation).

Both Cerastoderma edule and Cerastoderma glaucum are eurytopic although C. glaucum tolerates wider ranges of temperatures and salinities (Zaouali, 1974). The larvae of $C$. edule cannot develop below the salinity of 16 (Eisma, 1965), whereas C. glaucum tolerates salinities down to 4 (Practical Salinity Scale) (Mars, 1950). The fact that $C$. glaucum tolerates high temperatures better than $C$. edule is probably a consequence of its Mediterranean origin and is the reason why it can live in lagoons with water temperature exceeding $30^{\circ} \mathrm{C}$ during summer (Ansell et al., 1981; Wilson and Elkaim, 1997). However, C. glaucum lacks the tolerance to very loose, well-sorted sand, which is often characteristic of tidal regions (Brock, 1979). It was shown that $C$. glaucum is slower in reburying once washed out of the sand (Koulman and Wolff, 1977). Therefore, it prefers constant water levels prevailing in isolated lagoons of the Atlantic and parts of the North Sea, as well as the Baltic Sea, the Mediterranean Sea, the Black Sea and the Caspian Sea. C. edule is present from the subtropical coast of West Africa to the Arctic Barents Sea, excluding marginal seas such as the Baltic and the Mediterranean (Hayward and Ryland, 1995). Its distribution is much less fragmented than that of C. glaucum (Brock, 1979, 1980), because it prefers sheltered, but open tidal zones. There are several areas where the two cockle species live in sympatry in Portugal (Machado and Costa, 1994), Finland (Rygg, 1970), Germany (Reise, personal communication), Norway, Sweden, Denmark, Netherlands, England and France (Brock, 1987).

A priori biological and ecological differences between Cerastoderma glaucum and Cerastoderma edule are grouped in the Table 1 and will be addressed in more detail later.

Previous studies were mainly focused on morphological and genetic discrimination of both cockle species (see above), as well as comparison of their ecology and physiology (e.g., Rygg, 1970; Boyden, 1972; Brock, 1979, 1980; Lindegarth et al., 1995; Wilson and Elkaim, 1997). Genetic variability of some European
Table 1

A priori biological differences between $C$. edule and C. glaucum.

\begin{tabular}{|c|c|c|}
\hline & C. edule & C. glaucum \\
\hline Fragmentation of habitat & Low & Moderate to high \\
\hline Larval duration & About 5 weeks & Usually $1-2$ weeks \\
\hline Commercial value & Moderate to high & None or low \\
\hline $\begin{array}{l}\text { Possibility of dispersal } \\
\text { by ships ballast }\end{array}$ & Moderate & Low \\
\hline $\begin{array}{l}\text { Possibility of dispersal } \\
\text { by migrating birds }\end{array}$ & Moderate & High \\
\hline
\end{tabular}

populations of both species was analyzed using isoenzyme electrophoresis (Hummel et al., 1994). Here, for the first time the population genetic structures (mitochondrial DNA) of a substantial number of populations of these two well characterized sister species are compared to elucidate the factors shaping evolutionary history. This is a comparative analysis of the fragments of the data published before concerning each of two cockle species separately (Tarnowska et al., 2010; Krakau et al., 2012). The hypothesis states that differences in habitat types and life history are reflected in the genetic structure patterns of these two cockles indicating the important role of extrinsic and intrinsic factors in phylogeography.

\section{Materials and methods}

\subsection{Sampling, DNA extraction, amplification and sequencing of fragments of the cytochrome oxidase subunit I (COI) gene}

Samples of Cerastoderma edule were collected from 17 locations and of Cerastoderma glaucum from 13 locations (Fig. 1), and tissue was stored in 95\% ethanol. Total DNA was extracted from adductor muscle or foot tissue (about $1 \mathrm{~mm}^{3}$ ) following the protocol of the Qiagen DNeasy Blood and Tissue Kit. For C. glaucum a DNA fragment of $580 \mathrm{bp}$ and for $C$. edule a fragment of about $700 \mathrm{bp}$ were amplified and sequenced as described in Tarnowska et al. (2010) and Krakau et al. (2012) respectively. Finally, DNA of 335 individuals of $C$. edule and 250 individuals of $C$. glaucum were analyzed. For the complete datasets for each species refer to Tarnowska et al. (2010) and Krakau et al. (2012).

\subsection{Data analyses}

Sequences from both species were aligned using the BIOEDIT software (Hall, 1999) and a 506 bp fragment was chosen for further analysis. The calculation of the average uncorrected percent of sequence differences between both species, and the amino acid translation of the sequences were made using MEGA4 (Tamura et al., 2007). The number of segregating sites $(S)$, haplotype diversity $\left(H_{D}\right)$ and nucleotide diversity $(\pi)(\mathrm{Nei}, 1987)$ were computed using the program DNASP v.4.10.9 (Rozas et al., 2003), as well as $D$ statistics of Tajima (1989) aimed at testing the hypothesis of neutrality, which assumes the absence of selection affecting the genetic marker and a stable effective population size. Allelic richness was calculated with the CONTRIB software (R. J. Petit, available at: http://www.pierroton.inra.fr/genetics/labo/Software/index. html). It was standardized to cope with uneven sample sizes with the rarefaction procedure. The relationship between the intrapopulation genetic diversity component of allelic richness (after rarefaction) and latitude was investigated. Data from four sites, from which both cockle species were sampled in close locations, were used to create a phylogenetic haplotype network based on the median-joining vectors method and generated with NETWORK v.4.5 (Bandelt et al., 1999). 


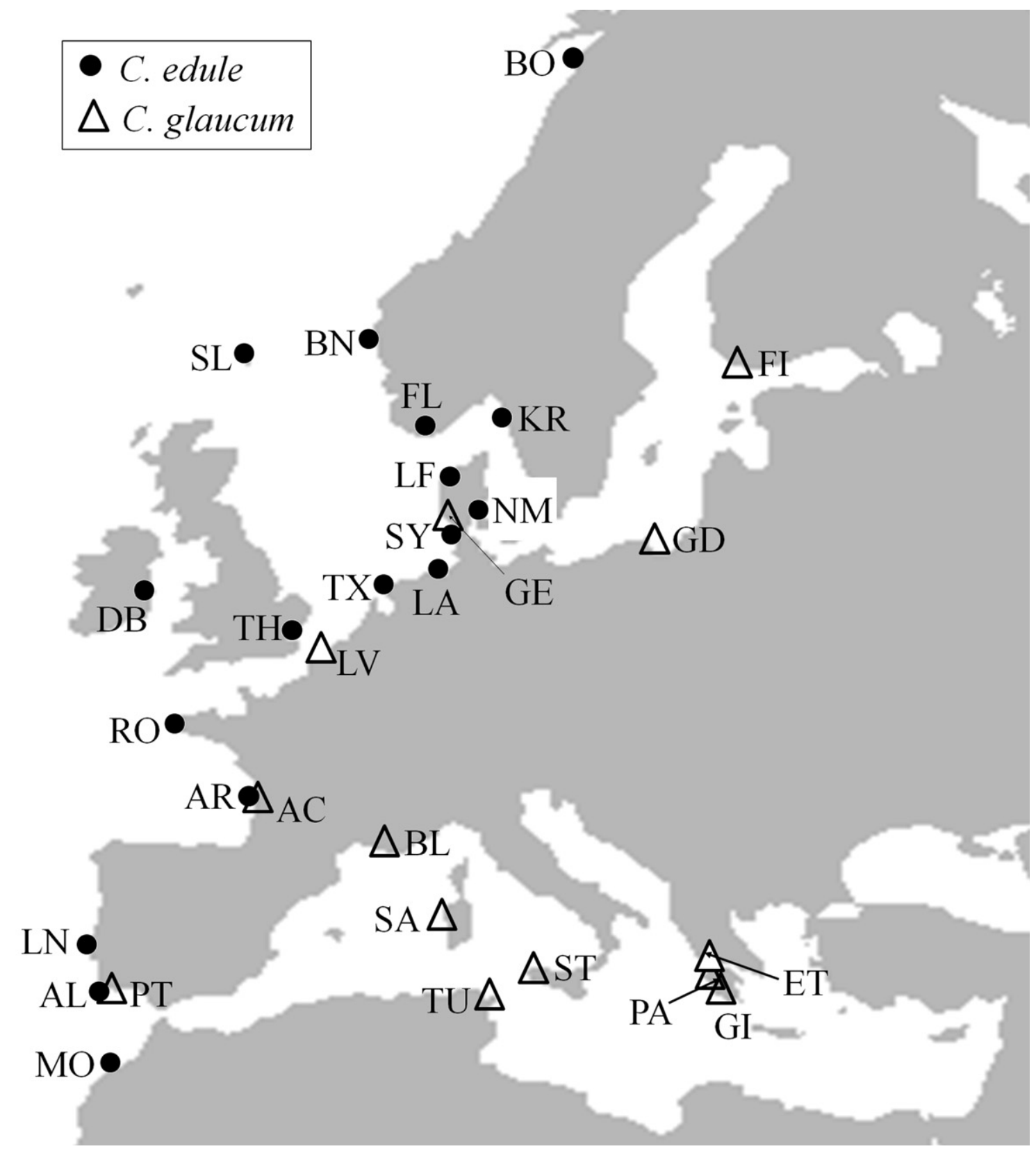

Fig. 1. Sampling locations for the two cockle species: (a) C. edule, marked with black circles, (b) C. glaucum, marked with transparent triangles. See Table 2 for site definitions.

Pairwise $F_{\mathrm{ST}}$ values between population pairs (Weir and Hill, 2002) were computed using ARLEQUIN v.3.1 (Excoffier et al., 2005). The non-metric multidimensional scaling (MDS) of $F_{S T}$ values (XLstat 7.5.2) was applied allowing the presentation of levels of differentiation between populations of each species without assuming tree-like relationships. Genetic structures of the cockles were also examined with the analysis of molecular variance (AMOVA, Excoffier et al., 1992) using ARLEQUIN v.3.1 (Excoffier et al., 2005). To test the significance, 1000 permutations were performed. Populations were divided into groups corresponding to geographic regions. The grouping tested for Cerastoderma edule was: the Norwegian Sea (BN, BO), the Danish Straits (FL, KR, NM), the North Sea (LF, SY, LA, TX, SL), the English Channel and the Atlantic Ocean (DB, TH, RO, AR, LN, AL, MO). For Cerastoderma glaucum the populations were divided into 5 groups: the Baltic Sea (GD, FI), the North Sea (GE, LV), the Atlantic
Ocean (AC, PT), the Mediterranean Sea (BL, SA, TU, ST) and the Ionian Sea (GI, ET, PA).

Mantel tests were performed for both species within their common distribution area (the Atlantic Ocean and the North Sea) in order to verify whether the genetic structure corresponds to the isolation by distance model.

\section{Results}

\subsection{Intraspecific genetic structure in both species}

For our comparative study we used 335 sequences of Cerastoderma edule, which included 64 haplotypes. For Cerastoderma glaucum, we analyzed 250 sequences which corresponded to 74 haplotypes. The average uncorrected difference between all C. glaucum and all C. edule haplotypes found in this study was of 
26.50\%. Translating DNA sequences into amino acids revealed one non-synonymous mutation in C. glaucum haplotypes and five nonsynonymous mutations in $C$. edule haplotypes. All of them were individual singletons. Apart from these haplotypes, there was no difference in the amino acids composition of the analyzed COI part between both species.

Intraspecific structuring was much more pronounced in Cerastoderma glaucum than in Cerastoderma edule (Fig. 2). In C. glaucum, only three out of $88 F_{\mathrm{ST}}$ values were not significant (FIGD, LV-AC, ET-PA) (Table S1 in the Supplement) $(\alpha=0.05)$. Geographically close population pairs often had significant (e.g., North Sea, LV-GE: 0.19) and very high (Atlantic, AC-PT: 0.92; Western Mediterranean, SA-ST: 0.87, SA-BL: 0.77, $p<0.01) F_{\mathrm{ST}}$ values. These values between population pairs from the same basin were similar to the values between the most distant and the most divergent populations in the $C$. edule dataset (LA-MO: 0.82 , LA-AL: 0.80). In C. edule, populations could be divided into two large geographic groups with the border between them in the region of the English Channel. Two populations from Skagerrak (FL, KR) were difficult to attribute to one of these groups (Figs. 1 and 2a). After excluding these two populations, the $F_{\mathrm{ST}}$ value between the two main population groups was $0.57(p<0.01)$. However, many haplotypes were shared between these groups or differed by a single mutation (data not shown). The $F_{S T}$ values were not significant among numerous geographically close populations (e.g., most of the populations from the North Sea, SY-LATX-SL, and from the Atlantic Ocean, RO-AR-LN, and both populations from Skagerrak, FL-KR) (Table S1 in the Supplement). For C. glaucum, among group molecular variation explained $24.4 \%$ of molecular variation, among populations within groups molecular variation, $56.1 \%$ of molecular variation and within population molecular variation, $19.5 \%$. The values of fixation indices were $F_{\mathrm{CT}}=0.24(p=0.03)$ (among groups), $F_{\mathrm{SC}}=0.74(p<0.001)$ (among populations within groups), $F_{\mathrm{ST}}=0.81(p<0.001)$ (among populations). As for $C$. edule, when the populations were grouped according to geographic regions, among groups molecular variation explained $42.7 \%$ of molecular variation, among populations within groups molecular variation explained $2.8 \%$ of molecular variation and within population molecular variation, $54.5 \%$. The values of fixation indices were $F_{\mathrm{CT}}=0.43, F_{\mathrm{SC}}=0.05, F_{\mathrm{ST}}=0.46$ (all significant $p<0.001$ ).

At four sites both species were sampled in nearby localities: at the Atlantic coasts of Portugal (AL and PT) and France (AR and AC), in the English Channel (at opposite sides of it: TH and LV) and in the North Sea, in Germany (SY and GE) (Fig. 1, Table 2). Samples from these sites were analyzed in more detail. The haplotype network including these four populations of each species revealed that the most divergent population in Cerastoderma edule was the one from the North Sea (SY) ( $0.7 \%$ of mean distance) and in case of Cerastoderma glaucum the one from Portugal (PT) $(1.7 \%$ of mean distance) (Fig. 3).

The Mantel test performed for both species on all populations from the North Sea and the Atlantic Ocean revealed a correlation between geographical and genetic distances for Cerastoderma edule (test performed on 11 populations) ( $p<0.05$ ), but not for Cerastoderma glaucum (test performed on 4 populations) $(p>0.05)$. However, when the number of $C$. edule populations was reduced to the four sites of nearby occurrence to $C$. glaucum, the Mantel test did not reveal a correlation between geographical and genetic distances $(p>0.05)$.

\subsection{Diversity within populations in both species}

The intrapopulation diversity in Cerastoderma edule increased to the north, whereas in Cerastoderma glaucum, it increased to the southern direction (Fig. 4a). The square of correlation coefficient $\left(R^{2}\right)$, which is a measure of the reliability of the linear relationship between the $x$ and the $y$ values, was similar for both species with the total dataset $(0.46$ and 0.49$)$. However, there were several exceptions from these general trends, as both for $C$. glaucum and for $C$. edule on local geographical scales the relationships between latitude and genetic diversity were sometimes opposite (Fig. 4a). The contrasting pattern of latitude diversity was confirmed when only the four sites where both species co-occurred were taken into consideration (Fig. 4b). In C. edule, the highest allelic richness after rarefaction (with the sample size set to 10) was found in the Norwegian Sea (5.25). The mean allelic richness of the populations from the North Sea was 3.59. Three populations located on the southern limit of our samples set, not far from the entrance to the Mediterranean Sea, had a mean allelic richness of 1.82. In contrast, $C$. glaucum populations from the North Sea and the Baltic Sea had a mean allelic richness of 1.58, from the Atlantic 2.70 and populations from the Mediterranean 3.72 (Table 2). The neutrality tests performed on each sampled populations yielded significant results for $C$. glaucum for three out of the four localities sampled for both species: two Atlantic coast populations (AC, $p<0.01$; PT, $p<0.05$ ) and one North Sea population (LV, $p<0.01$ ). In the case of $C$. edule, the results of neutrality tests were significant only for one population, the one from the Irish Sea (DB, $p<0.05)$.


Fig. 2. Metric multidimensional scaling (MDS) of population pairwise $F_{\mathrm{ST}}$ values: (a) C. edule (stress $=0.127$ ); (b) $C$. glaucum (stress $=0.226$; stress value over 0.2 suggests that the precision in representing the relationships among populations is limited). Main geographical regions are indicated for each species. 
Table 2

Abbreviations and geographic coordinates of sampling sites and genetic diversity of samples. $N$ - number of individuals, $N_{H}-$ number of haplotypes, b[10]-1 - allelic richness after rarefaction to $10, N_{U}$ - number of unique haplotypes, $S$ - number of polymorphic sites, $H_{D}$ - haplotype diversity, $\pi$ - nucleotide diversity.

\begin{tabular}{|c|c|c|c|c|c|c|c|c|c|c|}
\hline Region & Site & Code & Coordinates & $N$ & $N_{H}$ & $\mathrm{~b}[10]-1$ & $N_{U}$ & $S$ & $H_{D}$ & $\Pi$ \\
\hline \multicolumn{11}{|l|}{ C. edule } \\
\hline \multirow[t]{2}{*}{ Norwegian Sea } & Bodoe, Norway & BO & $67^{\circ} 17^{\prime} \mathrm{N}, 14^{\circ} 37^{\prime} \mathrm{E}$ & 22 & 11 & 6.32 & 5 & 12 & 0.93 & 0.59 \\
\hline & Bergen, Norway & $\mathrm{BN}$ & $60^{\circ} 23^{\prime} \mathrm{N}, 05^{\circ} 20^{\prime} \mathrm{E}$ & 22 & 8 & 4.19 & 3 & 11 & 0.77 & 0.35 \\
\hline \multirow[t]{2}{*}{ Skagerrak } & Arendal, Norway & $\mathrm{FL}$ & $58^{\circ} 26^{\prime} \mathrm{N}, 08^{\circ} 48^{\prime} \mathrm{E}$ & 20 & 8 & 4.89 & 2 & 12 & 0.87 & 0.57 \\
\hline & Kristineberg, Sweden & $\mathrm{KR}$ & $58^{\circ} 14^{\prime} \mathrm{N}, 11^{\circ} 26^{\prime} \mathrm{E}$ & 20 & 7 & 3.53 & 1 & 7 & 0.64 & 0.37 \\
\hline Kattegat & Norsminde, Denmark & NM & $56^{\circ} 02^{\prime} \mathrm{N}, 10^{\circ} 25^{\prime} \mathrm{E}$ & 20 & 8 & 4.87 & 2 & 9 & 0.86 & 0.53 \\
\hline \multirow[t]{5}{*}{ North Sea } & Limfjord, Denmark & LF & $56^{\circ} 97^{\prime} \mathrm{N}, 09^{\circ} 20^{\prime} \mathrm{E}$ & 19 & 9 & 4.60 & 4 & 8 & 0.77 & 0.40 \\
\hline & Sylt, Germany & SY & $55^{\circ} 01^{\prime} \mathrm{N}, 08^{\circ} 26^{\prime} \mathrm{E}$ & 19 & 11 & 5.79 & 6 & 15 & 0.87 & 0.45 \\
\hline & Langeoog, Germany & LA & $53^{\circ} 45^{\prime} \mathrm{N}, 07^{\circ} 29^{\prime} \mathrm{E}$ & 21 & 4 & 1.83 & 2 & 6 & 0.41 & 0.15 \\
\hline & Texel, the Netherlands & $\mathrm{TX}$ & $53^{\circ} 13^{\prime} \mathrm{N}, 04^{\circ} 94^{\prime} \mathrm{E}$ & 20 & 6 & 2.50 & 2 & 6 & 0.45 & 0.20 \\
\hline & North Gluss, Great Britain & SL & $60^{\circ} 28^{\prime} \mathrm{N}, 01^{\circ} 21^{\prime} \mathrm{W}$ & 20 & 6 & 3.25 & 1 & 6 & 0.71 & 0.31 \\
\hline Irish Sea & Dublin, Ireland & DB & $53^{\circ} 19^{\prime} \mathrm{N}, 06^{\circ} 12^{\prime} \mathrm{W}$ & 23 & 6 & 2.17 & 4 & 7 & 0.40 & 0.12 \\
\hline English Channel & Southend, Great Britain & $\mathrm{TH}$ & $51^{\circ} 28^{\prime} \mathrm{N}, 00^{\circ} 42^{\prime} \mathrm{E}$ & 21 & 8 & 4.12 & 5 & 10 & 0.72 & 0.28 \\
\hline \multirow[t]{5}{*}{ NE Atlantic } & Roscoff, France & RO & $48^{\circ} 72^{\prime} \mathrm{N}, 03^{\circ} 97^{\prime} \mathrm{W}$ & 23 & 10 & 4.43 & 7 & 13 & 0.73 & 0.29 \\
\hline & Arcachon, France & $\mathrm{AR}$ & $44^{\circ} 35^{\prime} \mathrm{N}, 01^{\circ} 14^{\prime} \mathrm{W}$ & 13 & 3 & 1.73 & 1 & 4 & 0.41 & 0.15 \\
\hline & Lisbon, Portugal & LN & $38^{\circ} 43^{\prime} \mathrm{N}, 09^{\circ} 00^{\prime} \mathrm{W}$ & 10 & 3 & 2.00 & 1 & 5 & 0.51 & 0.26 \\
\hline & Lagos, Portugal & $\mathrm{AL}$ & $37^{\circ} 07^{\prime} \mathrm{N}, 08^{\circ} 37^{\prime} \mathrm{W}$ & 21 & 5 & 2.17 & 3 & 5 & 0.42 & 0.11 \\
\hline & Merja Zerga, Morocco & MO & $34^{\circ} 50^{\prime} \mathrm{N}, 06^{\circ} 14^{\prime} \mathrm{W}$ & 21 & 3 & 1.42 & 0 & 2 & 0.40 & 0.08 \\
\hline \multicolumn{11}{|l|}{ C. glaucum } \\
\hline \multirow[t]{2}{*}{ Baltic Sea } & Tvärminne, Finland & $\mathrm{FI}$ & $59^{\circ} 50^{\prime} \mathrm{N}, 23^{\circ} 15^{\prime} \mathrm{E}$ & 24 & 4 & 1.91 & 1 & 3 & 0.43 & 0.09 \\
\hline & Gdynia, Poland & GD & $54^{\circ} 40^{\prime} \mathrm{N}, 18^{\circ} 30^{\prime} \mathrm{E}$ & 18 & 3 & 1.37 & 1 & 2 & 0.31 & 0.06 \\
\hline \multirow[t]{2}{*}{ North Sea } & Ellenbogen, Sylt, Germany & GE & $55^{\circ} 02^{\prime} \mathrm{N}, 8^{\circ} 24^{\prime} \mathrm{E}$ & 19 & 3 & 1.99 & 0 & 2 & 0.69 & 0.18 \\
\hline & Lake Veere, the Netherlands & LV & $51^{\circ} 35^{\prime} \mathrm{N}, 3^{\circ} 38^{\prime} \mathrm{E}$ & 19 & 3 & 1.05 & 1 & 9 & 0.21 & 0.19 \\
\hline \multirow{2}{*}{ Northeastern Atlantic } & Arcachon, France & AC & $44^{\circ} 41^{\prime} \mathrm{N}, 1^{\circ} 03^{\prime} \mathrm{W}$ & 32 & 11 & 3.13 & 10 & 10 & 0.53 & 0.14 \\
\hline & Ria Formosa, Portugal & PT & $37^{\circ} 00^{\prime} \mathrm{N}, 7^{\circ} 58^{\prime} \mathrm{W}$ & 22 & 6 & 2.27 & 5 & 7 & 0.41 & 0.13 \\
\hline \multirow{4}{*}{ Western Mediterranean } & Etang de Berre, France & $\mathrm{BL}$ & $43^{\circ} 24^{\prime} \mathrm{N}, 5^{\circ} 08^{\prime} \mathrm{E}$ & 21 & 11 & 5.16 & 8 & 19 & 0.81 & 0.57 \\
\hline & Cabras, Sardinia & SA & $39^{\circ} 56^{\prime} \mathrm{N}, 8^{\circ} 31^{\prime} \mathrm{E}$ & 21 & 10 & 4.81 & 7 & 10 & 0.78 & 0.34 \\
\hline & Rades, Tunisia & TU & $36^{\circ} 47^{\prime} \mathrm{N}, 10^{\circ} 17^{\prime} \mathrm{E}$ & 25 & 10 & 5.08 & 5 & 15 & 0.86 & 0.74 \\
\hline & Sicily, Italy & ST & $37^{\circ} 47^{\prime} \mathrm{N}, 12^{\circ} 26^{\prime} \mathrm{E}$ & 17 & 6 & 3.61 & 2 & 5 & 0.77 & 0.22 \\
\hline \multirow[t]{3}{*}{ Ionian Sea } & Etolikon, Greece & ET & $38^{\circ} 28^{\prime} \mathrm{N}, 21^{\circ} 18^{\prime} \mathrm{E}$ & 10 & 7 & 6.00 & 4 & 15 & 0.91 & 0.99 \\
\hline & Papas Lagoon, Greece & PA & $38^{\circ} 12^{\prime} \mathrm{N}, 21^{\circ} 22^{\prime} \mathrm{E}$ & 11 & 6 & 4.51 & 3 & 15 & 0.73 & 0.89 \\
\hline & Gialova, Greece & GI & $36^{\circ} 57^{\prime} \mathrm{N}, 21^{\circ} 40^{\prime} \mathrm{E}$ & 11 & 4 & 2.82 & 1 & 8 & 0.60 & 0.45 \\
\hline
\end{tabular}

\section{Discussion}

The analyses revealed several notable differences in the genetic structure patterns of the two cockle species. The main disparities consist of: (1) a general higher level of interpopulation divergence in Cerastoderma glaucum than in Cerastoderma edule, (2) a very high level of divergence between some geographically close populations of $C$. glaucum, contrasted with the genetic similarities among populations of $C$. edule within geographical regions, (3) intrapopulation
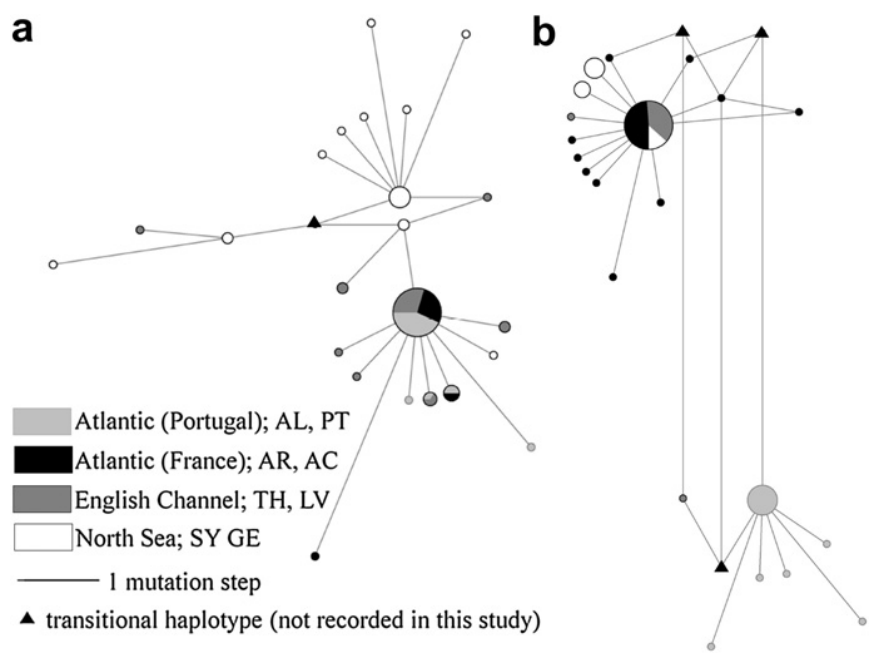

Fig. 3. Haplotypes networks of (a) C. edule and (b) C. glaucum restricted to haplotypes from the four sites where both species co-occur. diversity within $C$. edule increasing toward the north, and in C. glaucum, decreasing toward the north. Different intrinsic and extrinsic factors have influenced both species since their divergence. Main possible explanations of factors shaping differences in genetic structure of these cockles are grouped in Table 3 and discussed below.

\subsection{Geographical and hydrological barriers}

Relatively little genetic structuring was found among geographically close populations of Cerastoderma edule (MDS, AMOVA and Mantel test), in accordance with previous allozymes analysis of populations from the southern British coast (Beaumont and Pether, 1996) and other European sites (Hummel et al., 1994). The low level of genetic structuring is probably due to a continuous distribution area, which facilitates gene flow. In this species tides together with water currents present in the Atlantic Ocean play the important role in the larval transport. However, gene flow seems to be impeded in the region of the English Channel, which has been shown to act as a barrier for larval dispersal in many marine invertebrates (e.g., Roman and Palumbi, 2004; Jolly et al., 2005; Derycke et al., 2008). The internal counterclockwise circulation patterns in the central and northern North Sea may play a role as a distribution barrier (Brown et al., 1999).

In contrast to Cerastoderma edule, the lagoon cockle Cerastoderma glaucum is present in the Mediterranean. In general, coastal currents are much faster in the Atlantic than in the Mediterranean, which was evoked as a probable reason of the differences in the dispersal rates of Sargassum muticum (Shanks et al., 2003 and references therein). Theoretically, this could account for differences in dispersal distances of planktonic larvae between 

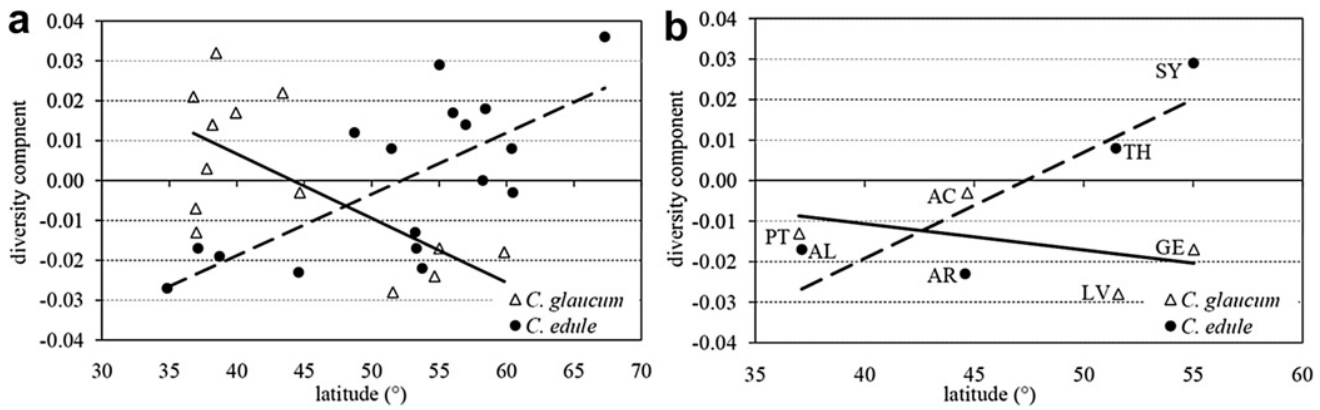

Fig. 4. The relationship between the diversity component of allelic richness (after rarefaction to the population size of 10) and latitude (a) For all the populations; $C$. glaucum: $y=-0.0016 x+0.0712, R^{2}=0.46$; C. edule: $y=0.0015 x-0.0803, R^{2}=0.49$ (b) Populations from the sites from where both species were sampled; C. glaucum: $y=-0.0006 x+0.0152, R^{2}=0.25$, C. edule: $y=0.0026 x-0.1241, R^{2}=0.75$.

these cockle species. However, the lagoon cockle often inhabits isolated water bodies and is thus much more influenced by geographical barriers to gene flow than $C$. edule at open intertidal coasts. We consider habitat fragmentation to be the main factor shaping the genetic structure of $C$. glaucum. It leads to a high level of genetic structuring among populations, which is a typical pattern of lagoon species (Johnson and Black, 1998; Darling et al., 2004; Astolfi et al., 2005). However, there are some areas like e.g., the Baltic Sea, where $C$. glaucum forms continuous populations along a large part of the coastal zone. The two populations from the Baltic Sea are genetically similar to each other, which supports the hypothesis that habitat continuity is a major factor influencing gene flow in Cerastoderma. Water currents appear to play little role in the long distance transport of $C$. glaucum larvae, because of the habitat fragmentation. The consequence of low level of gene flow among C. glaucum populations could be the lower recolonization capacity compared to C. edule, which is crucial for the conservation of local populations.

\subsection{Planktonic larvae properties}

In sessile benthic organisms the planktonic larvae play an important role in population dispersal and exploring new habitats. Both cockle species investigated here have planktonic larvae. However, the duration of the larval stage is of approximately five weeks in the intertidal Cerastoderma edule and much shorter in Cerastoderma glaucum (Boyden, 1971; Barnes, 1980). In C. glaucum, metamorphosis usually starts after less than two weeks (Lauckner, 1972; Kingston, 1974; Wołowicz, 1987). The duration of the planktonic larval stage is often considered to reflect the dispersal capacity (e.g., Hellberg et al., 2002). For many species this duration is positively correlated with dispersal distance (reviewed in Shanks et al., 2003). Therefore, even in the absence of geographical barriers, the short duration of the larval stage of $C$. glaucum alone could theoretically explain a higher genetic structure among populations than in C. edule. However, the duration of the larval stage may vary within species (e.g., Mytilus galloprovincialis: 14 days to 6 weeks, Mytilus californianus: 9-45 days) (Becker et al., 2007) and may depend on environmental conditions (e.g., temperature: O'Connor et al., 2007 and references therein). Local variations in life-history parameters, such as larval duration, but also delay of metamorphosis, initiation of spawning, local mortality or vertical position of the larvae within the water column, may provoke differences in the genetic structures of two closely-related species as shown for Mytilus (Becker et al., 2007). On the other hand, there are many proofs that gene flow is not necessarily proportional to the duration of the larval stage (e.g., Todd et al., 1998; Eckert, 2003; Teske et al., 2007). Closely-related species with similar life history and dispersal abilities may have contrasting levels of genetic structuring (Patarnello et al., 2007). Moreover, a comparative study of 41 species with pelagic development proved that the duration of the planktonic larval phase is uncorrelated with overall population subdivision (Kelly and Palumbi, 2010 and references therein).

\subsection{Alternative dispersal means}

The natural dispersal by planktonic larvae is not the only dispersal means accessible to cockles. A widely discussed dispersal vector of marine organisms is ship ballast water, which caused numerous invasions of non-native species (reviewed in Carlton and Geller, 1993). The transport of planktonic larvae in ballast water seems possible for both cockles, but more likely for Cerastoderma edule, as the most typical habitats of Cerastoderma glaucum are often excluded from ships' circulation as they have little connection with an open sea or ocean. Moreover, water has been used as ship ballast only since around 1900 (Fofonoff et al., 2003), so it might only be a very recent factor influencing gene flow. Solid ballast, which had been used before, could play a role in dispersal of benthic species, but not for cockles, which require a sandy bottom.

Table 3

A simplified comparison of genetic structures of C. glaucum and C. edule, and possible factors provoking certain traits.

\begin{tabular}{|c|c|c|c|}
\hline Genetic structure trait & C. edule & C. glaucum & Possible explaining factors \\
\hline Diversity within population & Low to high & Low to high & $\begin{array}{l}\text { - Mortality } \\
\text { - Recruitment } \\
\text { - Effective population size } \\
\text { - Demographic history }\end{array}$ \\
\hline $\begin{array}{l}\text { Differentiation between } \\
\text { neighboring populations }\end{array}$ & Low & $\begin{array}{l}\text { High to extremely high, } \\
\text { geographical discontinuities }\end{array}$ & $\begin{array}{l}\text { - Fragmentation of habitat } \\
\text { - Duration of planktonic larval stage } \\
\text { - Different dispersal modes }\end{array}$ \\
\hline Latitudinal gradient of genetic diversity & Increasing to the north & Increasing to the south & $\begin{array}{l}\text { - Genetic drift and founder effect after extinction events } \\
\text { due to Pleistocene glaciations } \\
\text { - Possible glacial refugia in the north in case of } C \text {. edule }\end{array}$ \\
\hline
\end{tabular}


The common cockle Cerastoderma edule is a popular sea food in several European countries and may be influenced directly by human transport, as was the case for Mytilus edulis, where the absence of clear division within European populations was attributed to aquaculture based mixing (Riginos and Henzler, 2008). In addition, dredging of cockles could provoke local homogenization of populations (Ferns et al., 2000; Piersma et al., 2001; Leitao and Gaspar, 2007). However, there is no indication on that code of practice for cockle farmers in Europe. In contrast, Cerastoderma glaucum has a marginal commercial value (Arjonilla et al., 1994), but it may be transported accidentally with aquacultured species or as a result of other anthropogenic activities. Lagoons and estuaries proved to be common sites for anthropogenic introduction of alien species (Ruiz et al., 1997). Nevertheless, our studies do not show any clear indications for detectable human influence on genetic population structures in both species.

In conclusion, long distance dispersal through planktonic larvae, for aquaculture purposes or with ballast water seems unlikely for Cerastoderma glaucum. Potential vectors of dispersal of cockles on different geographical scales are birds which may externally transport juveniles attached to algae or other debris or adults attached directly to birds' foot or neck. Past and present long distance dispersal via migrating birds may to some extent explain geographical discontinuities in the genetic structure of $C$. glaucum (discussed in Tarnowska et al., 2010, 2012). Eggs of C. glaucum stick to the surface of submerged plants, and juveniles climb and attach to substrata with their byssal gland, so they could be transported on birds together with plants (Reise, 2003). Although, Cerastoderma edule is a morphological sibling of $C$. glaucum and could be theoretically transported in the same way, we do not observe geographical discontinuities in genetic structure. In this species the main dispersal means seems to be its planktonic larvae. However, successful recruitment of larvae is the condition of effective dispersal. In the case of $C$. edule, recruitment was proved to be influenced by many factors, such as predation on postlarvae, sediment composition or fisheries (Beukema and Dekker, 2005).

\subsection{Local adaptations and selection}

Tolerance to environmental factors have an important influence on present distribution areas, in particular on its fragmentation, and consequently on genetic structure. Both Cerastoderma glaucum and Cerastoderma edule seem to display high phenotypic plasticity. For example, it has been suggested that $C$. glaucum is able to regulate its metabolism by reducing energy expenditure to survive at high temperatures (Wilson and Elkaim, 1997). Apart from phenotypic plasticity, local adaptations may also enable the cockles to inhabit given environmental conditions (Tarnowska et al., 2009). Especially in C. glaucum, local selection might have influenced genetic structures, as habitat fragmentation reduces gene flow between localities and thus helps locally adapted genes to increase in frequency as a result of natural selection. A possible selection signature was detected in this species in one microsatellite locus (Tarnowska et al., 2010). The neutrality tests gave significant results for $C$. glaucum at three out of four sites from where both species were sampled from nearby locations in the North Sea and Atlantic. It suggests that the lagoon cockle is subject to either selection or to demographic fluctuations in these areas (Hartl and Clark, 1997). Neutrality tests were not significant for $C$. edule from the corresponding sites. If the reason of the significant results of neutrality test for three populations of $C$. glaucum is demographic fluctuations, rather than a selective sweep, this suggests that the (re) colonization of these areas is more recent for $C$. glaucum than for C. edule, so the populations expand demographically. In the case of C. edule the neutrality test was significant only for the population from Ireland (DB), which suggests either a selective event or a recent (after glaciations) reduction of population size followed by demographic expansion.

\subsection{Pleistocene events influencing present genetic structures in both species}

Genetic structures of species with distribution areas reaching the north of Europe are often still reflecting the influence of Pleistocene glaciations. Due to the lack of suitable habitats during ice ages, northern populations are assumed to be (re)established after glaciations. Therefore, southern populations are considered older. They usually bear higher genetic diversity than their northern counterparts, which have experienced severe genetic drift due to bottlenecking and/or founder events associated with postglacial colonization (reviewed in Hewitt, 2000; Maggs et al., 2008). In Cerastoderma glaucum, the south-north pattern of genetic diversity reflects this common assumption. In contrast, the intrapopulation diversity of Cerastoderma edule increases northwards. Although the general patterns of genetic diversity seem contrasting, the results should be interpreted with caution, as within regions the genetic diversities are sometimes variable and the trends are not straightforward. The high genetic diversity of $C$. edule in the northern regions (almost 3 times higher than in C. glaucum near the Sylt Island, Germany) is unexpected taking into account the young geologic age of this region (about 8000 years before present). Moreover, this diversity seems to have evolved in the north, as many haplotypes present in the north are not retrieved in the south. The presence of $C$. edule in glacial refugia in the north would be the simplest explanation of this pattern, but their existence is still under debate. However, several recent studies support the idea of northern refugia with the first strong indication on the existence of glacial refugia in the western English Channel area (Stewart and Lister, 2001; Riginos and Henzler, 2008; Provan and Bennett, 2008; Maggs et al., 2008).

\section{Conclusions}

Present-day genetic patterns of sister species may reveal important differences being a synergic effect of many past and present processes. Therefore, specifying factors shaping these differences is an opportunity to better understand the importance and the effects of gene flow, selection and other mechanisms. The results of this study suggest that differences in species-specific factors can result in the development of quite disparate patterns of population genetic structure and phylogeography for species of the same origin.

\section{Acknowledgments}

We thank all those who helped us with sample collection of C. glaucum: E. Egea, H. Hummel, J. Jansen, B. Kelemen, T. Kevrekidis, T. Kontula, R. Lasota, M. Machado, A. E. Mogias, G. Sara, T. Sjölund, R. Sussarellu, R. Väinölä, J. Zaouali and staff at the University of Patras. For sample support of $C$. edule we thank H. Bazairi, J. Coyer and J. Olsen, E.A. Genelt-Yanovsky, K. Korsnes, D. Lackschewitz, X. de Montaudouin, S. Mortensen, J. Saunders, K. Valentin and A. Wagner. We acknowledge Karsten Reise for helpful comments. This work was partly supported by the "Genetic Biodiversity" GBIRM project (MarBEF European Network of Excellence contract no. GOCE-CT2003-505446).

\section{Appendix A. Supplementary data}

Supplementary data associated with this article can be found, in the online version, at doi:10.1016/j.ecss.2012.05.007. 


\section{References}

André, C., Lindegarth, M., Jonsson, P.R., Sundberg, P., 1999. Species identification of bivalve larvae using random amplified polymorphic DNA (RAPD): differentiation between Cerastoderma edule and C. lamarcki. Journal of the Marine Biological Association of the UK 79, 563-565.

Ansell, A.D., Barnett, P.R.O., Bodoy, A., Massé, H., 1981. Upper temperature tolerances of some European mollusks. Marine Biology 65, 177-183.

Arjonilla, M., Forja, J.M., Gomez-Parra, A., 1994. Sediment analysis does not provide a good measure of heavy metal bioavailability to Cerastoderma glaucum (Mollusca: Bivalvia) in confined coastal ecosystems. Bulletin of Environmental Contamination and Toxicology 52, 810-817.

Astolfi, L., Dupanloup, I., Rossi, R., Bisol, P.M., Faure, E., Congiu, L., 2005. Mitochondrial variability of sand smelt Atherina boyeri populations from north Mediterranean coastal lagoons. Marine Ecology Progress Series 297, 233-243.

Bandelt, H.J., Forster, P., Rohl, A., 1999. Median-joining networks for inferring intraspecific phylogenies. Molecular Biology and Evolution 16, 37-48.

Barnes, R.S.K., 1980. Coastal Lagoons. Cambridge University Press, Cambridge, United Kingdom, 106 pp.

Beaumont, A.R., Pether, S.M.J., 1996. Allozyme variation and gene flow between cockle Cerastoderma edule populations in southern United Kingdom. Fisheries Research 28, 263-275.

Becker, B.J., Levin, L.A., Fodrie, F.J., McMillan, P.A., 2007. Complex larval connectivity patterns among marine invertebrate populations. Proceedings of the National Academy of Science of the USA 104, 3267-3272.

Bermingham, E., Moritz, C., 1998. Comparative phylogeography: concepts and applications. Molecular Ecology 7, 367-369.

Beukema, J.J., Dekker, R., 2005. Decline of recruitment success in cockles and other bivalves in the Wadden Sea: possible role of climate change, predation on postlarvae and fisheries. Marine Ecology Progress Series 287, 149-167.

Boyden, C.R., 1971. A comparative study of the reproductive cycle of the cockles Cerastoderma edule and C. glaucum. Journal of the Marine Biological Association of the United Kingdom 51, 605-622.

Boyden, C.R., 1972. The behaviour, survival and respiration of the cockles Cerastoderma edule and C. glaucum in air. Journal of the Marine Biological Association of the United Kingdom 52, 661-680.

Brock, V., 1978. Morphological and biochemical criteria for separation of Cardium glaucum (Bruguière) from Cardium edule (L.). Ophelia 17, 207-214.

Brock, V., 1979. Habitat selection of two congeneric bivalves, Cardium edule and C. glaucum in sympatric and allopatric populations. Marine Biology 54, $149-156$.

Brock, V., 1980. Evidence of niche differences in sympatric populations of $C$. edule and C. lamarcki. Marine Ecology Progress Series 2, 75-80.

Brock, V., 1987. Genetic relations between the bivalves Cardium (Cerastoderma) edule, Cardium lamarcki and Cardium glaucum, studied by means of crossed immunoelectrophoresis. Marine Biology 93, 489-498.

Brock, V., Christiansen, G., 1989. Evolution of Cardium (Cerastoderma) edule, C. lamarcki and C. glaucum: studies of DNA-variation. Marine Biology 102 , 505-511.

Brown, J., Hill, A.E., Fernand, L., Horsburgh, K.J., 1999. Observation of a seasonal jetlike circulation at the central North Sea cold pool margin. Estuarine, Coastal and Shelf Science 48, 343-355.

Carlton, J.T., Geller, J.B., 1993. Ecological roulette: the global transport of nonindigenous marine organisms. Science $261,78-82$.

Costagliola, D., Robertson, D.R., Guidetti, P., Stefanni, S., Wirtz, P., Heiser, J.B., Bernardi, G., 2004. Evolution of coral reef fish Thalassoma spp. (Labridae). 2. Evolution of the eastern Atlantic species. Marine Biology 144, 377-383.

Darling, J.A., Reitzel, A.M., Finnerty, J.R., 2004. Regional population structure of a widely introduced estuarine invertebrate: Nematostella vectensis Stephenson in New England. Molecular Ecology 13, 2969-2981.

Derycke, S., Remerie, T., Backeljau, T., Vierstraete, A., Vanfleteren, J., Vincx, M., Moens, T., 2008. Phylogeography of the Rhabditis (Pellioditis) marine species complex: evidence for long-distance dispersal, and for range expansions and restricted gene flow in the northeast Atlantic. Molecular Ecology 17, 3306-3322.

Eckert, G.L., 2003. Effects of the planktonic period on marine population fluctuations. Ecology 84, 372-383.

Eisma, D., 1965. Shell characteristics of Cardium edule L. as indicators of salinity. Netherlands Journal of Sea Research 2, 493-540.

Excoffier, L., Laval, G., Schneider, S., 2005. Arlequin ver. 3.0: an integrated software package for population genetics data analysis. Evolutionary Bioinformatics Online $1,47-50$.

Excoffier, L., Smouse, P., Quattro, J., 1992. Analysis of molecular variance inferred from metric distances among DNA haplotypes: application to human mitochondrial DNA restriction data. Genetics 131, 479-491.

Ferns, P.N., Rostron, D.M., Siman, H.Y., 2000. Effects of mechanical cockle harvesting on intertidal communities. Journal of Applied Ecology 37, 464-474.

Fofonoff, P.W., Ruiz, G.M., Steves, B., Carlton, J.T., 2003. In ships or on ships? Mechanisms of transfer and invasion for nonnative species to the coasts of North America. In: Ruiz, G.M., Carlton, J.T. (Eds.), Invasive Species: Vectors and Management Strategies. Island Press, Washington, United States of America, pp. $152-182$.

Freire, R., Insua, A., Mendez, J., 2005. Cerastoderma glaucum 5S ribosomal DNA: characterization of the repeat unit, divergence with respect to Cerastoderma edule, and PCR-RFLPs for the identification of both cockles. Genome 48, 427-442.

Gosling, E.M., 1980. Gene frequency changes and adaptation in marine cockle. Nature 286, 601-602

Hall, T.A., 1999. BioEdit: a user-friendly biological sequence alignment editor and analysis program for Windows 95/98/NT. Nucleic Acids Symposium Series 41, 95-98.

Hanel, R., Westneat, M.W., Sturmbauer, C., 2002. Phylogenetic relationships, evolution of broodcare behavior, and geographic speciation in the wrasse tribe Labrini. Journal of Molecular Evolution 55, 776-789.

Hartl, D.L., Clark, A.G., 1997. Principles of Population Genetics, third ed. Sinauer Associates, Sunderland, Massachussetts, United States of America, $542 \mathrm{pp}$.

Hayward, P.J., Ryland, J.S., 1995. Handbook of the Marine Fauna of North-West Europe. Oxford University Press, Oxford, 800 pp.

Hellberg, M.E., Burton, R.S., Neigel, J.E., Palumbi, S.R., 2002. Genetic assessment of connectivity among marine populations. Bulletin of Marine Science 70, $273-290$.

Hewitt, G.M., 2000. The genetic legacy of quaternary ice ages. Nature 405, 907-913.

Hsü, K., Montadert, L., Bernoulli, D., Cita, M.B., Erickson, A., Garrison, R.E., Kidd, R.B., Melieres, F., Müller, C., Wright, R.C., 1977. History of the Mediterranean salinity crisis. Nature 267, 399-403.

Hummel, H., Wołowicz, M., Bogaards, R.H., 1994. Genetic variability and relationships for populations of Cerastoderma edule and of the C. glaucum complex. Netherlands Journal of Sea Research 33, 81-89.

Johnson, M.S., Black, R., 1998. Increased genetic divergence and reduced genetic variation in populations of the snail Bembicium vittatum in isolated tidal ponds. Heredity 80, 163-172.

Jolly, M.T., Jollivet, D., Gentil, F., Thiebaut, E., Viard, F., 2005. Sharp genetic break between Atlantic and English Channel populations of the polychaete Pectinaria koreni, along the North coast of France. Heredity 94, 23-32.

Kelly, R.P., Palumbi, S.R., 2010. Genetic structure among 50 species of the northeastern Pacific rocky intertidal community. PLoS ONE 5 (1), e8594.

Kingston, P., 1973. Interspecific hybridization in Cardium. Nature 243, 360.

Kingston, P., 1974. Some observations on the effects of temperature on the growth of Cardium edule and Cardium glaucum larvae in the laboratory. Journal of the Marine Biological Association of the United Kingdom 54, 309-317.

Koulman, J.G., Wolff, W.J., 1977. The Mollusca of the estuarine region of the rivers Rhine, Meuse, and Scheldt in relation to the hydrography of the area. V. the Cardiidae. Basteria 41, 21-32.

Krakau, M., Jacobsen, S., Jensen, K.T., Reise, K., 2012. The cockle Cerastoderma edule at Northeast Atlantic shores: genetic signatures of glacial refugia. Marine Biology 159, 221-230.

Ladhar-Chaabouni, R., Hardivillier, Y., Chénais, B., Hamza-Chaffai, A., Denis, F., 2010. Pilot study for genetic differentiation between two phenotypes of the Mediterranean population of $C$. glaucum and genetic discrimination between this population and others of $C$. glaucum and $C$. edule outside the Mediterranean. Marine Ecology and Evolutionary Perspective 31, 355-363.

Lauckner, G., 1972. Zur taxonomie, ökologie und physiologie von Cardium edule L. und Cardium lamarcki Reeve. Dissertation, University of Kiel, $261 \mathrm{pp}$

Leitao, F.M.S., Gaspar, M.B., 2007. Immediate effect of intertidal non-mechanised cockle harvesting on macrobenthic communities: a comparative study. Scientia Marina 71, 723-733.

Levy, A., 1985. Une nouvelle conception de l'origine énigmatique des Cerastoderma glaucum quaternaires du Sahara. Comptes-rendus de l'Académie des Sciences de Paris 301, 437-442.

Lindegarth, M., Andre, M.C., Jonsson, P.R., 1995. Analysis of the spatial variability in abundance and age structure of two infaunal bivalves, Cerastoderma edule and C. lamarcki, using hierarchical sampling programs. Marine Ecology Progress Series 116, 85-97.

Machado, M.M., Costa, A.M., 1994. Enzymatic and morphological criteria for distinguishing between Cardium edule and C. glaucum of the Portuguese coast. Marine Biology 120, 535-544

Maggs, C.A., Castilho, R., Foltz, D.W., Henzler, C., Jolly, M.T., Kelly, J., Olsen, J., Perez, K.E., Stam, W., Väinölä, R., Viard, F., Wares, J., 2008. Evaluating signatures of glacial refugia for North Atlantic benthic marine taxa. Ecology 89, s108-s122.

Mars, P., 1950. Euryhalinité de quelques mollusques méditerranéens. Vie Millieu 1, $441-448$.

McMillen-Jackson, A.L., Bert, T.M., 2003. Disparate patterns of population genetic structure and population history in two sympatric penaeid species in the southeastern United States. Molecular Ecology 12, 2895-2905.

Müller, P., Geary, D.H., Magyar, I., 1999. The endemic molluscs of the Late Miocene Lake Pannon: their origin, evolution, and family-level taxonomy. Lethaia 32, 47-60.

Nei, M., 1987. Molecular Evolutionary Genetics. Columbia University Press, New York, United States of America, $512 \mathrm{pp}$.

Nikula, R., Väinölä, R., 2003. Phylogeography of Cerastoderma glaucum (Bivalvia: Cardiidae) across Europe: a major break in the eastern Mediterranean. Marine Biology 143, 339-350.

O'Connor, M.I., Bruno, J.F., Gaines, S.D., Halpern, B.S., Lester, S.E., Kinlan, B.P., Weiss, J.M., 2007. Temperature control of larval dispersal and the implications for marine ecology, evolution and conservation. Proceedings of the National Academy of Sciences USA 104, 1266-1271.

Palumbi, S.R., 1994. Genetic divergence, reproductive isolation, and marine speciation. Annual Review of Ecology and Systematics 25, 547-572. 
Patarnello, T., Volckaert, F.J., Castilho, R., 2007. Pillars of Hercules: is the AtlanticMediterranean transition a phylogeographical break? Molecular Ecology 16, 4426-4444.

Piersma, T., Koolhaas, A., Dekinga, A., Beukema, J.J., Dekker, R., Essink, K., 2001 Long-term indirect effects of mechanical cockle-dredging on intertidal bivalve stocks in the Wadden Sea. Journal of Applied Ecology 38, 976-990.

Provan, J., Bennett, K.D., 2008. Phylogeographic insights into cryptic glacial refugia. Trends in Ecology and Evolution 23, 564-571.

Reise, K., 2003. Metapopulation structure in the lagoon cockle Cerastoderma lamarcki in the northern Wadden Sea. Helgoland Marine Research 56, 252-258.

Riginos, C., Henzler, C.M., 2008. Patterns of mtDNA diversity in North Atlantic populations of the mussel Mytilus edulis. Marine Biology 155, 399-412.

Roman, J., Palumbi, S.R., 2004. A global invader at home: population structure of the green crab, Carcinus maenas, in Europe. Molecular Ecology 13, 2891-2898.

Rozas, J., Sánchez-DelBarrio, J.C., Messeguer, X., Rozas, R., 2003. DNA polymorphism analyses by coalescent and other methods. Bioinformatics 19, 2496-2497.

Ruiz, G.M., Carlton, J.T., Grosholz, E.D., Hines, A.H., 1997. Global invasions of marine and estuarine habitats by non-indigenous species. Mechanisms, extent, and consequences. American Zoologist 37, 621-632.

Rygg, B., 1970. Studies on Cerastoderma edule (L.) and Cerastoderma glaucum (Poiret). Sarsia 43, 65-80.

Shanks, A.L., Grantham, B.A., Carr, M.H., 2003. Propagules dispersal distance and the size and spacing of marine reserves. Ecological Applications 13 (Suppl. 1), S159-S169.

Stewart, J.R., Lister, A.M., 2001. Cryptic northern refugia and the origins of the modern biota. Trends in Ecology and Evolution 16, 608-613.

Tajima, F., 1989. Statistical method for testing the neutral mutation hypothesis by DNA polymorphism. Genetics 123, 585-595.

Tamura, K., Dudley, J., Nei, M., Kumar, S., 2007. MEGA4: molecular evolutionary genetics analysis (MEGA) software version 4.0. Molecular Biology and Evolution 24, 1596-1599.
Tarnowska, K., Chenuil, A., Nikula, R., Féral, J.P., Wołowicz, M., 2010. Complex genetic population structure of bivalve (Cerastoderma glaucum) living in highly fragmented lagoon habitat. Marine Ecology Progress Series 406, 173-184.

Tarnowska, K., Verney, A., Wołowicz, M., Féral, J.P., Chenuil, A., 2012. Survival of male and female Cerastoderma glaucum (Bivalvia) during aerial exposure. Vie et milieu-life and environment 62 (1), 23-28.

Tarnowska, K., Wołowicz, M., Chenuil, A., Féral, J.P., 2009. Comparative studies on morphometry and physiology of European populations of the lagoon specialist Cerastoderma glaucum (Bivalvia). Oceanologia 51, 437-458.

Teske, P.R., Papadopoulos, I., Zardi, G.I., McQuaid, C.D., Edkins, M.T., Griffiths, C.L., Barker, N.P., 2007. Implications of life history for genetic structure and migration rates of southern African coastal invertebrates: planktonic, abbreviated and direct development. Marine Biology 152, 697-711.

Todd, C.D., Lambert, W.J., Thorpe, J.P., 1998. The genetic structure of intertidal populations of two species of nudibranch molluscs with planktotrophic and pelagic lecithotrophic larval stages: are pelagic larvae "for" dispersal? Journal of Experimental Marine Biology and Ecology 228, 1-28.

Valsecchi, E., Pasolini, P., Bertozzi, M., Garoia, F., Ungaro, N., Vacchi, M., Sabelli, B. Tinti, F., 2005. Rapid miocene-pliocene dispersal and evolution of Mediterranean rajid fauna as inferred by mitochondrial gene variation. Journal of Evolutionary Biology 18, 436-446.

Weir, B.S., Hill, W.G., 2002. Estimating F-statistics. Annual Review of Genetics 36 , 721-750.

Wilson, J.G., Elkaim, B., 1997. Seasonal and geographical differences in oxygen consumption with temperature of Cerastoderma glaucum (Poiret) and a comparison with C. edule (L.). Estuarine, Coastal and Shelf Science 45, 571-577.

Wołowicz, M., 1987. Larval development of Cardium glaucum and C. hauniense (Bivalvia) from the Gdansk Bay. Polskie Archiwum Hydrobiologii 34, 107-117.

Zaouali, J., 1974. La faune malacologique du lac de Tunis (parties Nord et Sud) et de ses canaux (Canal Central, Canal Nord et Canal Sud ). Haliotis 4, 179-186. 